Canadian Journal of Higher Education Revue canadienne d'enseignement supérieur

Volume 43, No. 1, 2013, pages 80-99

\title{
Service Learning as a Practicum Experience in a Pre-Service Education Program
}

Nancy Maynes, Blaine Hatt, \& Ron Wideman

Nipissing University

\begin{abstract}
This paper presents research on the benefits of service learning for pre-service teachers in the final year of their concurrent education program. The purpose of the research was to determine whether liberatory learning (Chambers, 2009) occurred for those students during a four-week service learning placement in organizations other than schools. Liberatory learning involves transformational shifts in social consciousness and provides service of benefit to both the participant and the host organization. Seventeen pre-service teachers and service learning supervisors completed questionnaires. Results suggest that service learning has the potential to be liberatory for pre-service teachers, but learning may remain tacit rather than explicit unless substantial opportunities for reflection are included in the service learning experience. Debriefing activities following the experience may be a critical contributor to helping participants realize the nature and extent of their learning.
\end{abstract}

\section{Résumé}

Cet article présente des résultats de recherche portant sur le sujet des avantages de l'apprentissage par le service communautaire pour des enseignants stagiaires dans la dernière année de leur programme d'études simultanées (Concurrent Education Program). Cette recherche visait à déterminer si ces futurs enseignants avaient fait preuve d'apprentissage libératrice ( «liberatory learning», Chambers, 2009), au cours d'un stage de quatre semaines d'apprentissage par le service, dans un cadre en dehors des écoles. L'apprentissage libératrice comprend des changements transformationnels en conscience sociale, et un mode de service dont profitent également 
les participants et l'établissement hôte. Dix-sept stagiaires et autant de superviseurs du programme d'apprentissage par le service ont rempli des questionnaires. Leurs réponses donnent à croire que l'apprentissage par le service offer la possibilité d'être libératrice, mais démontrent aussi que l'apprentissage peut rester plutôt implicite, au lieu de s'exprimer explicitement, à moins que l'expérience ne comporte beaucoup d'occasions de réflexion. Les activités de débriefing après le stage représentent sans doute une composante essentielle pour aider les participants à se rendre compte du contenu et de l'ampleur de leur apprentissage.

This paper presents research investigating the benefits of service learning for Nipissing University pre-service teachers in the final year of their concurrent education program. In concurrent education, pre-service teachers take simultaneously their undergraduate Arts and Science and Education programs, graduating after five years with both a Bachelor of Arts or Science and a Bachelor of Education. Education courses are taken in each year of the program, and over the five years, 26 weeks are dedicated to practice teaching.

Service learning involves a cycle of service action accompanied by opportunities for reflection. Theoretically, service learning is based in a discipline and structured to focus on individual identity formation through personal growth and socio-centric engagement (Chambers, 2009). The experience of service learning is designed to achieve real organizational objectives for the host community organization and a deeper understanding of their learning for students (Eyler \& Giles, 1999).

We intended to investigate the advantages of dedicating four of the practice-teaching weeks in the concurrent education program to a service learning placement. In this placement, pre-service teachers would work in organizations serving school-age children in non-school settings. However, we were unable to find research studies on the impact of service learning in teacher preparation contexts, and it appeared that service learning has not been widely used as an approach to enriching teacher preparation through alternative forms of practica.

Consequently, when we established a four-week service learning placement for our 34 final-year pre-service teachers, we asked them and their host supervisors to complete surveys about the benefits, limitations, and future structure of the service learning experience. In this paper, we contextualize this research in the service learning literature, describe the methodology of the study, and explore the results, particularly in relation to the four levels of service learning identified by Chambers (2009):

Level 1 - Experiential Learning: The service is an isolated experience. The participant is less engaged with those who are served and takes an observer role.

Level 2 - Social Learning: The service provides the participant with potential impacts, personally and educationally. The focus is on what the participant takes from the experience by learning about other social conditions in the larger community.

Level 3 - Student Development: The participant is focused on expanding his or her own skill set. 
Level 4 - Liberatory Learning: The service provides the participant with an opportunity for social change and transformational shifts in social consciousness. The participant and the community partner both give and get service in a spirit of reciprocity.

Our goal for the pre-service teachers was that they experience a liberatory level of service learning during their placement. Our research seems to have confirmed that this goal was substantially achieved. The results suggested that a concurrent pre-service education program rich in practicum time enabled a liberatory level of learning (Chambers, 2009) to occur and that service learning is a potentially significant, meaningful aspect of pre-service teacher preparation. We also concluded that increased opportunities for reflection are advisable in service learning placements to make liberatory learning explicit for participants.

\section{Contextualizing the Research in the Literature}

Since the beginning of the last decade, service learning has become more common as an approach for learning in a variety of higher education programs and has become an increasingly popular and powerful option for course andragogy (Campus Compact, 2002; Longo \& Meyer, 2006). Yet the literature on the role, benefits, structures, intentions, and impacts of service learning experiences in higher education is in its infancy in comparison with many other types of learning-related literature. Evidence that service learning has had the potential to improve learning outcomes has motivated institutions to explore service learning as an instructional strategy for deep understanding (Astin, Vogelgasong, Ikeda, \& Yee, 2000; Rawls, 1971). Service learning also provided the opportunity to combine academic subject matter in an integrated context when the placement allowed for and supported social engagement and critical reflection (Longo \& Meyer, 2006).

Service learning appears to offer students many potential benefits. These benefits include greater awareness of the links between theory and practice; preparation for a lifetime of informed participatory citizenship through a variety of personal and educational challenges; opportunities to think more deeply about the distribution and acquisition of resources, the environment, fairness, justice, and other social issues; the long-term positive impact of a service learning experience; opportunities to increase understanding and tolerance by engaging in different communities; and increased tolerance for diversity by development of new values, knowledge, and skills (Chambers, 2009).

Similarly, service learning offers many potential benefits for the community organizations that participate as service learning hosts. These benefits include increased awareness of the value and positive social outcomes of post-secondary education; the development of partnerships that support the organization; help with their efforts to improve the community; improved awareness of their community profile as seen by their service learning student; the potential long-term engagement of the student in their organization; and greater awareness gained from sources other than staff of the benefits of service, including recognizing societal values in practical service contexts (Chambers, 2009).

Chambers's critical approach to service learning provided the previously mentioned four-level framework of the potential impact of service learning experiences on participants. The levels-experiential learning, social learning, student development, and lib- 
eratory learning-are progressive: each level is structured with increasing expectations of learning outcomes and community benefits. The levels are also hierarchical: the potential impact on student learning is intensified as the agenda for their learning becomes more transformational in nature.

This liberatory model for service learning provides the potential for the greatest impact and immediate return in social transformation for the student and potentially for the long-range goals of the community. Only in the liberatory model of service learning does the community partner benefit from the reciprocity of engagement in service learning. This form of service learning may involve the service learning student in the everyday work of the organization and/or a different layer of service involving structured projects of interest to the host organization, including research (Marullo \& Edwards, 2000; Zlotkowski, 1996). For example, service learning students may investigate a site-related concept or issue and realize greater commitment and personal engagement to make a difference in their own or the broader community, enhanced by their deeper understanding of a concept or issue related to community and society (Borozangi, Greenwood, Burns, \& Finnie, 2003; Reardon, 1998; Schutz \& Ruggles, 1998; VanWynsberghe \& Andruske, 2007; Weinberg, 2003; Wiechman, 1996). Time limitations on such service learning placements are likely to influence the potential for this type of engagement if it is beyond the expertise that is offered to the host organization through the service learning partnership. Much more study of the benefits of service learning, however, is needed to determine how service learning meets the goals of community organizations and how it serves the learner through the experience of service to others.

Previous studies have identified positive or neutral outcomes of service learning experiences in relation to academic performance or affective states (Astin, Sax, \& Avalos, 1999; Eyler \& Giles, 1999; Gray et al., 1998; Tartter, 1996) and have indicated that service learning participants were more likely to participate in later service that benefits the community (Astin \& Sax, 1998; Boyle-Baise \& Kilbane, 2000; Rhodes, 1997). Additionally, service learning participation related to greater commitment to social issues and social responsibility (Astin \& Sax, 1998; Eyler \& Giles, 1999; Giles \& Eyler, 1994; Keen \& Keen, 1984). Service learning experiences with the greatest results in human behaviours were functions of each participant's meaning-making and related actions, informed by relevant academic information and the context of the community they served (Chambers, 2009).

The efficacy of a service learning opportunity related to its organization in terms of the time and effort, learning opportunities, and institutional support provided for the experience (Kuh, Kunzie, Schuh, Whitt, \& Associates, 1984). The time and effort participants devoted to processing thoughts and feelings about their service learning experience has predicted the growth resulting from their active engagement in community service (Austin, 1984; Ethington \& Horn, 2007; Pace, 1979, 1984). The most involved forms of service learning evidenced through liberatory approaches have supported the participants' development of critical consciousness (Friere, 1970) reflective of a social justice agenda for the community. Friere identified social change as a function of the individual's increasing clarity about his or her own values, concern for social equity, and willingness to act supportively to achieve community equity. Chambers (2009) combined critical thinking through discipline-based learning and honest dialogue as aspects of individual identity formation to achieve the critical consciousness that is a precursor to social justice and socio-centric engagement. 
Marullo and Edwards (2000) provided filters to determine support for different approaches to service learning. In their approach, a defining criterion for effective service learning was the engagement of all participants in problem solving to provide effective service. When service learning was managed at its most effective levels, many benefits resulted for both the participant and the community. These conditions (i.e., mutual involvement of both the servers and those who are served, problem-related tasks, and perceived effectiveness) echoed the levels of service learning evident in Chambers (2009). He contended that service learning approaches must be defined by the community's priorities and needs, the time available for service, the students' readiness to provide the needed service, the pedagogical philosophy of the originating academic program, the available community assets, and the community expectations for such partnerships.

Service learning opportunities were optimized through an expanded conception of their potential and the appropriate supports needed to realize that potential. Academically-supported examination of the factors that caused and contributed to social inequities and provided ways to change the causes and results of these inequities led to social transformation (Chambers, 2009; Green, Eckel, \& Hill, 1998). Chambers (2009) referred to this potential as the opportunity to "change and challenge the world" (p. 14). There is considerable evidence that well-conceived service learning experiences can support students to develop the self-awareness to examine their own contribution to complex societal problems and to address those problems in creative ways.

\section{Methodology}

Our initial conception of the goal of this study was to examine potential benefits for pre-service teachers in a service learning context. In the concurrent education program, all pre-service teachers take a practice-teaching course designed to prepare them for the realities of school placements. During this course, we met with fourth-year pre-service teachers to explain service learning to them and to situate service learning in their preservice program as a final-year practicum. We connected the service learning experience as a pre-service teaching practicum with opportunities to reflect on that experience through questionnaires that solicited both qualitative and quantitative data.

Following the initial meeting, pre-service teachers were sent an electronic version of our Service Learning Handbook which provides details of how they should arrange, report, and manage their service learning placement. Over the next eight months, they had opportunities to seek and receive support from the researchers and staff of the university's service learning office as they made decisions about the service learning placement of their choice. Sample organizations were provided and assistance in making initial contacts was available as requested.

Placement opportunities were found in a broad range of organizations such as libraries, museums, tutoring centres, alternative learning classrooms, early-year centres, charitable organizations, daycare centres, and day camps. Notwithstanding the research that demonstrated the value of site-related projects that addressed organizational needs (Marullo \& Edwards, 2000; Zlotkowski, 1996) and in keeping with the time limit of the service learning experiences in this study, we focused on placements where pre-service teachers arranged service situations that provided a significant teaching component. Sharing their teaching skills and their evolving curriculum and instructional expertise was expected to 
be of particular benefit to the on-site supervisor or other staff of the host organization. No other research or project related to organizational goals was required of participants.

Each placement choice was checked by the service learning office staff to ensure that it met the two essential criteria of providing work safety and affording the pre-service teacher a significant opportunity to use teaching skills in the context of the placement. Teacher candidates were required to complete 120 hours of service learning over a fourweek period in any configuration of hours that served them and the needs of their host organization.

The focus of the study then became the efficacy of service learning as a strategy to evolve the skills and attitudes of pre-service teachers and the specific outcomes of the experience from their perspective and that of their service learning supervisors. To examine this aspect of the experience, we designed two questionnaires, one to be completed by the pre-service teacher at the end of the service learning placement, and the other by the service learning supervisor of the host organization. The questionnaires for the pre-service teachers and the service learning supervisors contained 49 questions and 34 questions, respectively.

Both questionnaires shared a common structure. Most questions used a 5-point Likert scale (that is, strongly disagree, disagree, neutral, agree, strongly agree). Other questions either requested specific information about the respondent and the placement, or invited the respondent to provide qualitative comments. Questionnaires were designed to elicit reflection in six areas. The initial questions focused on information such as respondent age, gender, and experience. This section also asked the nature of the placement, specific duties performed, and the average number of hours a day worked within the organization. The second part of the questionnaire gathered information about the perceived value of the placement to the pre-service teacher and to the organization. The third part probed respondent reflections on the perceived value and importance of the services provided. The fourth part of the questionnaire assessed respondent attitudes toward community involvement, including perceived benefits and intentions to continue involvement. The fifth part of the questionnaire provided opportunities to express perceptions about the influence of this service learning experience on future professional work as a teacher. The final part of the questionnaire provided opportunities for personal reflections about the service learning experience, including perceptions of relationships established during placements, attitudes toward diversity, communication skills, applications of theoretical knowledge in new contexts, and intentions and efficacy beliefs about making a difference in their society. Copies of the questionnaires (adapted from Eyler \& Gyles, 1999, and Shinnamon, Gelmon, \& Holland, 1999) can be accessed on the university's concurrent education website (www.nipissingu.ca) through the Service Learning Handbook.

Both questionnaires focused on Chambers's (2009) levels of service learning during the placement. Because we agree with Chambers that liberatory learning subsumes the experiential learning, social learning, and student development approaches, we targeted awareness of liberatory service learning outcomes in 28 of our questions for pre-service teachers and 22 for service learning supervisors. Prompts reflected the social change focus of liberatory service learning experiences and the desired level of intentionality in the purposes of the experience. Examples of such questionnaire prompts include: 
The community participation aspect of this experience helped me to see how course material I learned can be used in everyday life.

Participation in service learning made me take more responsibility for my own learning.

Service learning made me more aware of the roles of educators in other disciplines besides teaching.

I felt I made a real contribution during my service learning experience.

All 34 final-year pre-service teachers completed their questionnaire and agreed to be part of the research study. However, only 17 organizational supervisors agreed to participate in the research study. Those supervisors who declined to participate did so for a variety of reasons mainly related to the structure of their respective organizations and the many supervisors who would have had to approve their participation. Therefore, we analyzed data from the 17 pre-service teachers and the 17 supervisors who had worked with them and agreed to participate in this study.

The questionnaire responses related to liberatory service learning are presented in Tables 1 and 2. Trends were identified through frequency analysis. Qualitative data were coded, summarized, displayed, and connected where appropriate with their quantitative counterparts. During the analysis, we sought to determine how responses revealed respondents' sense of the experiences, the social learning benefits of the experiences, preservice teachers' skill development, and the liberatory benefits of the experiences.

\section{Results from the Quantitative Data}

These results are reported in two parts. First, we address pre-service teacher perceptions of the benefits of their service learning practicum. Then we present the perceptions of the service learning placement supervisors from the host organizations.

\section{Pre-Service Teachers' Perceptions of the Benefits of a Service Learning Practicum}

Table 1 presents the results of the 28 questions that addressed liberatory service learning in the pre-service teacher questionnaire. Five themes of professional self-awareness were evident in the data: pre-service teachers' awareness of societal disparities; learning through giving service; awareness of personal growth; the intention to continue service to others; and a developing sense of personal efficacy when working with differences. From these themes, it is evident that Chambers's (2009) hierarchy was reflected in pre-service teachers' self-awareness related of the first three levels of service learning (that is, experiential learning, social learning, and student development). The themes of awareness of societal disparities, learning through giving service, and awareness of personal growth reflected these levels, levels that precede the attainment of a liberatory perspective. The themes of continuing service to others and developing a sense of personal efficacy when working with differences, on the other hand, indicated the social change and shift of consciousness outcomes of liberatory service learning. 
Table 1

Service Learning Questionnaire: Responses From Pre-Service Teachers

\begin{tabular}{|c|c|c|c|c|c|}
\hline Question Prompt & $\begin{array}{c}\% \\
\text { Strongly } \\
\text { Disagree }\end{array}$ & $\begin{array}{c}\% \\
\text { Disagree }\end{array}$ & $\begin{array}{c}\% \\
\text { Neutral }\end{array}$ & $\begin{array}{c}\% \\
\text { Agree }\end{array}$ & $\begin{array}{c}\% \\
\text { Strongly } \\
\text { Agree }\end{array}$ \\
\hline $\begin{array}{l}\text { The community participation aspect of } \\
\text { this experience helped me to see how } \\
\text { course material I learned can be used } \\
\text { in everyday life. }\end{array}$ & & 6.6 & 6.6 & 73.3 & $13 \cdot 3$ \\
\hline $\begin{array}{l}\text { Participation in service learning helped } \\
\text { me to better understand the material } \\
\text { from my lectures and readings. }\end{array}$ & & 20.0 & 33.3 & 40 & 6.6 \\
\hline $\begin{array}{l}\text { I feel I have gained a great deal of valu- } \\
\text { able information from my service } \\
\text { learning experience. }\end{array}$ & & & 6.6 & 26.6 & 66.6 \\
\hline $\begin{array}{l}\text { Service learning should be implemented } \\
\text { into more practica in my program. }\end{array}$ & 0.0 & 10.3 & 10.3 & 53.0 & 26.6 \\
\hline $\begin{array}{l}\text { My service learning experience was not } \\
\text { directly linked to building education } \\
\text { skills. }\end{array}$ & 20.0 & 66.6 & 6.6 & 6.6 & \\
\hline $\begin{array}{l}\text { Community service should be a voluntary } \\
\text { activity and not a practicum require- } \\
\text { ment. }\end{array}$ & 6.6 & 40.0 & 40.0 & 13.3 & \\
\hline $\begin{array}{l}\text { Service learning made me more aware of } \\
\text { the roles of educators in other disci- } \\
\text { plines besides teaching. }\end{array}$ & 6.6 & & 6.6 & 46.6 & 40 \\
\hline $\begin{array}{l}\text { I would like to enrol in additional service } \\
\text { learning experiences offered through } \\
\text { my concurrent program. }\end{array}$ & 6.6 & 6.6 & 20.0 & 53.3 & $13 \cdot 3$ \\
\hline $\begin{array}{l}\text { I had important duties during my service } \\
\text { learning experience. }\end{array}$ & & & & 66.6 & $33 \cdot 3$ \\
\hline $\begin{array}{l}\text { I had challenging tasks during my service } \\
\text { learning experience. }\end{array}$ & & 6.6 & 6.6 & 53.3 & $33 \cdot 3$ \\
\hline $\begin{array}{l}\text { What I did during my service learning } \\
\text { experience was interesting. }\end{array}$ & & & & $53 \cdot 3$ & 46.6 \\
\hline $\begin{array}{l}\text { I did things myself during my service } \\
\text { learning experience instead of observ- } \\
\text { ing. }\end{array}$ & & & 6.6 & 46.6 & 46.6 \\
\hline $\begin{array}{l}\text { I talked with people receiving service } \\
\text { during my service learning experience. }\end{array}$ & & & & 53.3 & 46.6 \\
\hline
\end{tabular}




\begin{tabular}{|c|c|c|c|c|c|}
\hline Question Prompt & 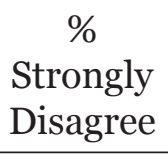 & $\begin{array}{c}\% \\
\text { Disagree }\end{array}$ & $\begin{array}{c}\% \\
\text { Neutral }\end{array}$ & $\begin{array}{c}\% \\
\text { Agree }\end{array}$ & $\begin{array}{l}\% \\
\text { Strongly } \\
\text { Agree }\end{array}$ \\
\hline $\begin{array}{l}\text { Professionals during my service learning } \\
\text { experience took an interest in me. }\end{array}$ & & & 6.6 & 46.6 & 46.6 \\
\hline $\begin{array}{l}\text { I had a variety of things to do during my } \\
\text { service learning experience. }\end{array}$ & & 6.6 & & 66.6 & 26.6 \\
\hline $\begin{array}{l}\text { I was appreciated when I did a good job } \\
\text { during my service learning experience. }\end{array}$ & & & & 46.6 & $53 \cdot 3$ \\
\hline $\begin{array}{l}\text { I felt I made a real contribution during } \\
\text { my service learning experience. }\end{array}$ & & & $13 \cdot 3$ & 40 & 46.6 \\
\hline $\begin{array}{l}\text { I was free to develop and use my own } \\
\text { ideas during my service learning expe- } \\
\text { rience. }\end{array}$ & & & 6.6 & 46.6 & 46.6 \\
\hline $\begin{array}{l}\text { I discussed my experiences with my } \\
\text { university adviser during my service } \\
\text { learning experience. }\end{array}$ & 20.0 & $33 \cdot 3$ & 26.6 & 6.6 & $13 \cdot 3$ \\
\hline $\begin{array}{l}\text { I worked with people from diverse ethnic } \\
\text { backgrounds during my service learn- } \\
\text { ing experience. }\end{array}$ & & 6.6 & $13 \cdot 3$ & $53 \cdot 3$ & 26.6 \\
\hline $\begin{array}{l}\text { I kept a daily journal during my service } \\
\text { learning experience. }\end{array}$ & 6.6 & $33 \cdot 3$ & $33 \cdot 3$ & 26.6 & \\
\hline $\begin{array}{l}\text { I had already done volunteer work before } \\
\text { this service learning experience. }\end{array}$ & & 14.28 & 14.28 & $35 \cdot 71$ & 35.71 \\
\hline $\begin{array}{l}\text { The community participation aspect of } \\
\text { service learning showed me how I can } \\
\text { become more involved in my commu- } \\
\text { nity. }\end{array}$ & & 13.3 & 20 & 46.6 & 20 \\
\hline $\begin{array}{l}\text { I will continue involvement specifically } \\
\text { with my service learning site. }\end{array}$ & & 14.28 & 14.28 & $35 \cdot 71$ & 35.71 \\
\hline $\begin{array}{l}\text { I feel that the work I did through service } \\
\text { learning benefited the community. }\end{array}$ & & & 21.42 & 57.14 & 21.42 \\
\hline $\begin{array}{l}\text { I will continue to volunteer in commu- } \\
\text { nity service after this experience. }\end{array}$ & & & 28.57 & 50 & 21.42 \\
\hline $\begin{array}{l}\text { Service learning helped me to become } \\
\text { more aware of the needs in the com- } \\
\text { munity. }\end{array}$ & & 7.1 & 21.42 & 57.14 & 14.28 \\
\hline $\begin{array}{l}\text { I have a responsibility to serve the com- } \\
\text { munity. }\end{array}$ & & & 7.1 & 71.42 & 21.42 \\
\hline
\end{tabular}




\begin{tabular}{|c|c|c|c|c|c|}
\hline Question Prompt & $\begin{array}{l}\% \\
\text { Strongly } \\
\text { Disagree }\end{array}$ & $\begin{array}{c}\% \\
\text { Disagree }\end{array}$ & $\begin{array}{c}\% \\
\text { Neutral }\end{array}$ & $\begin{array}{c}\% \\
\text { Agree }\end{array}$ & $\begin{array}{l}\% \\
\text { Strongly } \\
\text { Agree }\end{array}$ \\
\hline $\begin{array}{l}\text { Doing work in the community helped me } \\
\text { to define my personal strengths and } \\
\text { areas for growth. }\end{array}$ & & & 7.1 & 92.85 & \\
\hline $\begin{array}{l}\text { Performing work in the community } \\
\text { helped me clarify my career/specializa- } \\
\text { tion choice. }\end{array}$ & & & & 78.57 & 21.42 \\
\hline $\begin{array}{l}\text { I will integrate community service into } \\
\text { my future career plans. }\end{array}$ & & & 14.28 & 64.28 & 21.42 \\
\hline $\begin{array}{l}\text { I developed a good relationship with my } \\
\text { faculty adviser because of the commu- } \\
\text { nity work. }\end{array}$ & $13 \cdot 3$ & 26.6 & $33 \cdot 3$ & $13 \cdot 3$ & $13 \cdot 3$ \\
\hline $\begin{array}{l}\text { During this experience, I became more } \\
\text { comfortable working with people dif- } \\
\text { ferent from me. }\end{array}$ & & & 7.1 & 71.42 & 21.42 \\
\hline $\begin{array}{l}\text { Service learning made me more aware of } \\
\text { some of my own biases and prejudices. }\end{array}$ & 7.1 & 7.1 & $35 \cdot 71$ & 42.85 & 7.1 \\
\hline $\begin{array}{l}\text { Participating in the community helped } \\
\text { me enhance my leadership skills. }\end{array}$ & & & 21.42 & 64.28 & 14.28 \\
\hline $\begin{array}{l}\text { The service I provided in the community } \\
\text { enhanced my ability to communicate } \\
\text { my ideas in a real-world setting. }\end{array}$ & & & 7.1 & $85 \cdot 71$ & 7.1 \\
\hline $\begin{array}{l}\text { The service I provided helped me apply } \\
\text { things I had learned in class to real-life } \\
\text { situations. }\end{array}$ & 7.1 & & & $85 \cdot 71$ & 7.1 \\
\hline $\begin{array}{l}\text { My service helped me to understand how } \\
\text { rewarding it is to help others. }\end{array}$ & & & 7.1 & 64.28 & 28.57 \\
\hline $\begin{array}{l}\text { I can make a difference in the commu- } \\
\text { nity. }\end{array}$ & & & 7.1 & 57.14 & 35.71 \\
\hline
\end{tabular}

Note. Question prompts not listed here relate to the provision of statistical data (e.g., age, gender).

The opportunity to engage in service learning increased pre-service teachers' awareness of societal disparities. During their experience, $80 \%$ of the participants had opportunities to work with people from diverse ethnic backgrounds, $93 \%$ said that they became more comfortable working with people who were different from themselves, and 93\% agreed that service learning helped them to understand how rewarding it is to help others.

Service learning in the pre-service teacher program had dramatic impacts on pre-service teachers' understanding of what it meant to provide service to others. Eleven questions were related to pre-service teachers' sense of the value of the tasks they performed 
during service learning. These prompts elicited responses about the importance of the tasks, degree of challenge, interest, activity level and variety, interaction with those who were being served, supervisor responsiveness, and the variety of roles for educators in the community. All but one of these prompts elicited strong positive agreement about pre-service teachers' understanding of what it meant to provide service to others (that is, between $87 \%$ and $100 \%$ ).

The prompt that elicited exceptional patterns of response asked if the service learning experience made participants more aware of the roles of educators in disciplines other than teaching. Of the respondents, $47 \%$ disagreed or strongly disagreed, and the remaining respondents were neutral. It would appear that although pre-service teachers were increasingly aware of their understanding of what it meant to serve others, they were not inclined to adjust their personal career goals in response to their experiences. This perspective can be partially accounted for by considering that all service learning placements were required to include a significant teaching element. As a result, they may have perceived themselves as visiting pre-service teachers working in an alternate setting.

Service learning made participants more aware of their personal growth as professionals. Six prompts solicited information related to this awareness and supported dialogue about intentional personal growth through reflection. Of the respondents, 93\% agreed or strongly agreed that service learning had made them more responsible for their own learning (e.g., " My service learning experience helped me...). As well, 93\% agreed or strongly agreed that they had a responsibility to serve the community. Also evident were impacts on awareness of personal biases and prejudices (50\% agreed and $36 \%$ were neutral), developing leadership skills (79\% agreed or strongly agreed), and communication skills (93\% agreed or strongly agreed). All of the pre-service teachers indicated that service learning helped them clarify their career or specialization choices.

Finally, service learning influenced pre-service teachers' intentions to continue their involvement in community service learning. Of the respondents, $86 \%$ agreed or strongly agreed that they would integrate community service into their career plans, and 93\% felt they could make a difference in their community.

These findings echoed previous research that showed service learning participation related to greater commitment to social issues and social responsibility (Astin \& Sax, 1998; Eyler \& Giles, 1999; Giles \& Eyler, 1994; Keen \& Keen, 1984). Service learning experiences with the greatest fidelity resulted in human behaviours that were functions of each participant's meaning-making and related actions, informed by the relevant academic information and the context of the community they served (Chambers, 2009). Previous studies also identified positive or neutral outcomes of service learning experiences in relation to academic performance or affective states (Astin, Sax, \& Avalos, 1999; Eyler \& Giles, 1999; Gray et al., 1998; Tartter, 1996). They also indicated that service learning participants were more likely to participate in later service of benefit to the community (Astin \& Sax, 1998; BoyleBaise \& Kilbane, 2000; Rhodes, 1997). These findings were evident in this study as well.

\section{Community Partner Supervisors' Perception of the Benefits of a Service Learning Practicum}

Table 2 presents the results from the 22 questions that assessed liberatory service learning in the service learning supervisors' questionnaire. Service learning supervisors 
were strongly cognizant of their role in service learning. Of the supervisors, $83 \%$ felt that involvement of pre-service teachers benefited their business or agency. Similarly, $83 \%$ believed that having a pre-service teacher in their business or agency enabled them to define their strengths and areas for improvement as a community partner and helped them clarify their responsibility in this role. All supervisors responded that, as community partners, they were assisting in the education and employment preparation of university students, and $67 \%$ indicated that service learning helped them become more aware of the partnering needs of the university and the community. Overall, the high level of support for community service learning identified in community partner responses in this category of questions indicated endorsement of their role as community partners in this enterprise.

Table 2

Service Learning Questionnaire: Responses From Service Learning Supervisors

\begin{tabular}{|c|c|c|c|c|c|}
\hline Question Prompt & $\begin{array}{c}\text { \% } \\
\text { Strongly } \\
\text { Disagree }\end{array}$ & $\begin{array}{c}\% \\
\text { Disagree }\end{array}$ & $\begin{array}{c}\% \\
\text { Neutral }\end{array}$ & $\begin{array}{c}\% \\
\text { Agree }\end{array}$ & $\begin{array}{l}\% \\
\text { Strongly } \\
\text { Agree }\end{array}$ \\
\hline $\begin{array}{l}\text { The pre-service teacher's participation } \\
\text { in this practicum helped me to see how } \\
\text { course material learned in university } \\
\text { can be used in everyday life. }\end{array}$ & & & 16.6 & $83 \cdot 3$ & \\
\hline $\begin{array}{l}\text { Participation in service learning helped } \\
\text { me understand the importance of part- } \\
\text { nering with the university as a commu- } \\
\text { nity partner. }\end{array}$ & & & & 50.0 & 50.0 \\
\hline $\begin{array}{l}\text { I feel I have learned from my association } \\
\text { with a university teacher candidate in } \\
\text { the service learning experience. }\end{array}$ & & & 16.6 & $33 \cdot 3$ & 50.0 \\
\hline $\begin{array}{l}\text { Service learning should be implemented } \\
\text { in more practica in the education pro- } \\
\text { gram }\end{array}$ & & & & $33 \cdot 3$ & 66.6 \\
\hline \multicolumn{6}{|l|}{$\begin{array}{l}\text { My service learning experience helped } \\
\text { me: }\end{array}$} \\
\hline enhance my personal education skills. & & 16.6 & 50.0 & 16.6 & 16.6 \\
\hline enhance my interpersonal skills. & & 16.6 & 50.0 & $33 \cdot 3$ & \\
\hline enhance my communication skills. & 16.6 & & 50.0 & $33 \cdot 3$ & \\
\hline enhance my leadership skills. & & 16.6 & 50.0 & 16.6 & 16.6 \\
\hline enhance my mentoring skills. & & 16.6 & $33 \cdot 3$ & 16.6 & $33 \cdot 3$ \\
\hline enhance my partnering skills. & & 16.6 & $33 \cdot 3$ & $33 \cdot 3$ & 16.6 \\
\hline $\begin{array}{l}\text { take more responsibility in my role as a } \\
\text { community partner. }\end{array}$ & & 16.6 & $33 \cdot 3$ & 50 & \\
\hline
\end{tabular}




\begin{tabular}{|c|c|c|c|c|c|}
\hline Question Prompt & $\begin{array}{c}\% \\
\text { Strongly } \\
\text { Disagree }\end{array}$ & $\begin{array}{c}\% \\
\text { Disagree }\end{array}$ & $\begin{array}{c}\% \\
\text { Neutral }\end{array}$ & $\begin{array}{c}\% \\
\text { Agree }\end{array}$ & $\begin{array}{c}\% \\
\text { Strongly } \\
\text { Agree }\end{array}$ \\
\hline $\begin{array}{l}\text { Community service should be a vol- } \\
\text { untary activity and not a practicum } \\
\text { requirement. }\end{array}$ & & 83.3 & 16.6 & & \\
\hline $\begin{array}{l}\text { Service learning made me more aware of } \\
\text { the roles of educators in other disci- } \\
\text { plines besides teaching. }\end{array}$ & & $33 \cdot 3$ & 16.6 & 33.2 & 16.6 \\
\hline $\begin{array}{l}\text { I was already using volunteers before } \\
\text { this service learning experience. }\end{array}$ & & 16.6 & & 16.6 & 66.6 \\
\hline $\begin{array}{l}\text { I will accept another pre-service teacher } \\
\text { to continue my involvement in service } \\
\text { learning after this experience. }\end{array}$ & & & 16.6 & & $83 \cdot 3$ \\
\hline $\begin{array}{l}\text { I feel that the work the pre-service } \\
\text { teacher did through service learning } \\
\text { benefited my business/agency. }\end{array}$ & & & 16.6 & & $83 \cdot 3$ \\
\hline $\begin{array}{l}\text { Service learning helped me to become } \\
\text { more aware of the partnering needs } \\
\text { between the university and commu- } \\
\text { nity. }\end{array}$ & & & $33 \cdot 3$ & 50 & 16.6 \\
\hline $\begin{array}{l}\text { I have the opportunity through service } \\
\text { learning to assist in the education and } \\
\text { employment preparation of university } \\
\text { students. }\end{array}$ & & & & 66.6 & $33 \cdot 3$ \\
\hline $\begin{array}{l}\text { Having a pre-service teacher in my } \\
\text { business/agency helped me define my } \\
\text { strengths and areas for improvement } \\
\text { as a community partner. }\end{array}$ & & 16.6 & & $83 \cdot 3$ & \\
\hline $\begin{array}{l}\text { Having a pre-service teacher in my } \\
\text { business/agency helped me clarify my } \\
\text { responsibility as a community partner } \\
\text { in service learning. }\end{array}$ & & & 16.6 & $83 \cdot 3$ & \\
\hline $\begin{array}{l}\text { I will integrate community service into } \\
\text { my future business/agency plans. }\end{array}$ & & & $33 \cdot 3$ & 50 & 16.6 \\
\hline $\begin{array}{l}\text { I will give preference to applicants with } \\
\text { service learning experience in future } \\
\text { hiring. }\end{array}$ & & & $33 \cdot 3$ & 50 & 16.6 \\
\hline $\begin{array}{l}\text { I developed a good relationship with my } \\
\text { pre-service teacher during the service } \\
\text { learning experience. }\end{array}$ & & & 16.6 & $33 \cdot 3$ & 50 \\
\hline
\end{tabular}




\begin{tabular}{|c|c|c|c|c|c|}
\hline Question Prompt & $\begin{array}{c}\% \\
\text { Strongly } \\
\text { Disagree }\end{array}$ & $\begin{array}{c}\% \\
\text { Disagree }\end{array}$ & $\begin{array}{c}\% \\
\text { Neutral }\end{array}$ & $\begin{array}{c}\% \\
\text { Agree }\end{array}$ & $\begin{array}{c}\% \\
\text { Strongly } \\
\text { Agree }\end{array}$ \\
\hline $\begin{array}{l}\text { During this experience, I became more } \\
\text { comfortable working with university } \\
\text { contact staff who supervised place- } \\
\text { ments. }\end{array}$ & & & 83.3 & 16.6 & \\
\hline $\begin{array}{l}\text { Service learning made me more aware } \\
\text { of some of my own preferences and } \\
\text { priorities in selecting staff for my busi- } \\
\text { ness/agency. }\end{array}$ & & 16.6 & 16.6 & 50 & 16.6 \\
\hline $\begin{array}{l}\text { Participating as a community partner in } \\
\text { service learning helped me understand } \\
\text { I can make a difference in the commu- } \\
\text { nity. }\end{array}$ & & & 33.3 & 66.6 & \\
\hline
\end{tabular}

Note. Question prompts not listed here relate to the provision of statistical data (e.g., age, gender).

At the agency level, community partner supervisors indicated strong commitment to the value of service learning and the service it provided. Of the supervisors, $83 \%$ disagreed that service learning should be voluntary. In recognition of the value of the experience to both the pre-service teachers and to their businesses or agencies, $67 \%$ said they would give preference to service learning applicants in future hiring. An additional 33\% were neutral in response to this prompt. Supervisors also indicated that service learning experiences made them more aware of some of their own preferences and priorities in selecting staff for their business or agency (67\% agreed or strongly agreed) and helped them understand that they could make a difference in their community.

Many of the question prompts for community partner supervisors focused on potential improvements in the supervisor's skills that could accrue from involvement in community service learning. The responses indicated that supervisors realized improvements in their own interpersonal skills during their service learning experience (33\%), enhanced their personal communication (33\%), leadership (33\%), mentorship (50\%), and partnering skills (50\%). Overall, $83 \%$ of the supervisors felt that they had learned from their association with a pre-service teacher through the service learning experience. All believed that service learning should be implemented in more practica in the education program.

Community partner supervisors also indicated their intentions in relation to community service learning. In their responses, $83 \%$ were willing (that is, strongly agreed) to accept another pre-service teacher in the future and similarly indicated their desire to continue their involvement in service learning as a community partner. As a consequence, $67 \%$ of supervisors indicated that they would integrate community service learning into business or agency plans. 


\section{Results from the Qualitative Data}

Social change theory indicates that four theoretical levels are associated with service learning: experiential learning, social learning, student development, and liberatory learning (Chambers, 2009). Because we agreed that the liberatory level subsumes the other levels in Chambers's model, we focused our data analysis on the questions pertaining to the liberatory level and not on questions pertaining to lower levels. Our quantitative data were rich in positive responses from both the pre-service teachers and the community partners:

The experience was extremely beneficial. I think service learning should become a mandatory placement as it gives us (as students) an even greater opportunity to learn from others and become more well-rounded, experienced teachers!

The placement made me aware of not only other opportunities for careers but really what various communities offer to people-and how few people utilize the services that are provided within the community-free of charge!

However, when pre-service teachers were asked to add other comments about the service learning experience, their comments were mixed and could be divided into two groups. Some comments supported the quantitative results demonstrating strong awareness of, and support for, a liberatory perspective. The two examples above give testimony to this outcome. But the majority of comments were limited to lower levels of learning in Chambers's model and did not evidence liberatory learning. An example of this type of reflection is "I have now been hired part time at my service learning placement."

The following representative example from the qualitative data of liberatory learning is drawn from one pre-service teacher who contrasted the service learning experience with more traditional classroom teaching placements:

It took me a few days to become comfortable with the alternative setting because it was very different from a school. There is no set curriculum but an emergent curriculum based on children's interests. It was great to see a new approach to learning and once getting comfortable I loved the spontaneous learning and tasks that I engaged in and I had a chance to teach so much!! I didn't want to leave and wished I could spend the remainder of my placement there.

It is evident from this example that the student experienced her service learning placement in a liberatory sense (Chambers, 2009). She took a great deal from the experience by learning new approaches but also gave her growing teaching expertise to the organization as she developed comfort in the new context. Experientially, this pre-service teacher had a very strong emotive response to service learning. Social learning and personal student development are also evident in her reflection. Additionally, however, the preservice teacher demonstrated an increasing awareness of the transformation of her own thinking about her professionalism as she explored the amount of teaching she was able to contribute in this placement.

In contrast to the above, comments from most pre-service teachers failed to reinforce the liberatory or transformative awareness evident in the quantitative data. Additionally, 
many of these comments did not evidence social learning and therefore lacked an ingredient essential to the full realization of the transformative benefits of liberatory learning. One pre-service teacher stated, in a representative example, "From the first day, I had a great experience and time at the Center. Everyone was helpful and welcomed me. I learned new things every day that will help me in my future career of teaching." This comment did not evidence liberatory learning because it focused solely on what the preservice teacher took from the service learning experience rather than what the pre-service teacher contributed.

\section{Discussion}

We found that service learning results in positive learning outcomes for the participating students (Astin, Vogelgasang, Ikeda, \& Yee, 2000) in relation to all four levels of learning identified by Chambers, including liberatory learning. The nature of the outcomes, however, may depend on both the structure and the location of the service learning experience. For example, data demonstrate that when pre-service teachers serve in contexts most closely related to their teaching strengths, they feel they have the most to offer in their service to the organization. This phenomenon begs further research to determine the nature of placements that appear to be most beneficial to pre-service teacher growth. It may also be that the length of the service placement (four weeks) is too short to allow some participants to feel fully valued and effective, especially if they have to learn a new skill before they can begin to provide valued service to the organization.

The discrepancy between the quantitative data and the qualitative data in this study suggests that some pre-service teachers have tacit knowledge that is not expressed when they have opportunities to write freely about their experiences even though these ideas are expressed strongly in the quantitative data. This finding supports the idea that future service learning experiences in the pre-service program should include opportunities to make tacit knowledge explicit (Hannay, Wideman, \& Seller, 2006) through a post-placement debriefing activity that helps participants relate their learning to the four levels of learning in a social context (Chambers, 2009). Such a debriefing could take the form of focus group inquiry or could be managed as reflective practice experiences to provide pre-service teachers with opportunities to discuss their experiences, hear about the experiences of their colleagues, and examine patterns. This process, in addition to helping pre-service teachers make their tacit knowledge explicit, could provide some theoretical structure to help pre-service teachers reflect on the learning value of their service experiences. Comments such as the two provided above might be expanded through debriefing to make any deeper learning explicit.

Any deficiency in the comments may be attributable to two factors. First, the Likertscale questions may overemphasize the characteristics of liberatory education, leaving little room for further comment that pre-service teachers and community partners would consider to be relevant or additive. Second, despite regularly requiring pre-service teachers to include reflection in their learning episodes, we did not require daily reflection as part of this service learning experience. The only reflection opportunity was in the endof-placement questionnaire. The invitation to comment at the end of this questionnaire may have been worded in a way that failed to elicit reflection opportunities in the minds of respondents: "Please add any other comments you have about your service learning 
experience(s)." A more precisely worded invitation to comment may have resulted in different levels of responses. In future questionnaires, a required reflection that uses familiar reflective practice terminology may elicit more transformative responses that are consistent with and reinforce the trends indicated in the quantitative data.

\section{Conclusions}

Our research data reveal that liberatory approaches to service learning in a teacher preparation program have garnered considerable and enthusiastic support, in part because of potential benefits to both the teacher candidates and the communities they serve. In our study, the service learning placement was positively received by all involved. This outcome bodes well for service learning to continue to be an integral part of the practicum experience in our teacher education program.

Eyler and Giles (1998) asserted that structured reflection to aid students' efforts to internalize new understandings must be a goal for service learning. Our efforts to revise this part of the questionnaire will support reflections about the experiences so that the transformative power of those experiences may be more fully evident in comments as well as in quantitative responses. Austin (1984), Pace (1979, 1984), and Ethington and Horn (2007) noted that the time and effort participants devoted to processing thoughts and feeling about their service learning experience predicted their resulting growth. Consequently, the effort to adjust the questionnaires for this purpose is a worthwhile endeavour. The partial discrepancy between the quantitative data and the qualitative data gathered in this study highlights the need to include a structured debriefing activity in the service learning program to provide pre-service teachers with the opportunity to make tacit knowledge explicit through discussion of their experiences.

\section{References}

Astin, A. W., \& Sax, L. J. (1998). How undergraduates are affected by service participation. Journal of College Student Development, 39(3), 251-263.

Astin, A. W., Vogelgasang, L., Ikeda, E., \& Yee, J. (2000). How service learning affects students (Executive summary). Los Angeles, CA: University of California, Higher Education Research Institute.

Astin, A. W., Sax, L. J., \& Avalos, J. (1999). Long term effects of volunteerism during the undergraduate years. Review of Higher Education, 22(2), 187-202.

Astin, A. W. (1984). Student involvement: A development theory for higher education. Journal of College Student Personnel, 25, 297-308.

Borozangi, N. H., Greenwood, D. J., Burns, M. G., \& Finnie, J. L. (November, 2003). Evaluation model for an undergraduate action research program. Paper presented at the World We Want conference, Victoria, BC.

Boyle-Baise, M., \& Kilbane, J. (2000). What really happens? A look inside servicelearning for multicultural teacher education. Michigan Journal of Community Service Learning, 7, 54-64. 
Campus Compact. (2002). The new student politics: The Wingspread statement on student civic engagement. Providence, RI: Chambers, T.

Chambers, T. (2009). A continuum of approaches to service-learning within Canadian post-secondary education. Canadian Journal of Higher Education, 39(2), 77-100.

Eckel, P., \& Hill, B., Green, M. (1998). On change: En route to transformation (Occasional paper). Washington, DC: American Council on Education.

Ethington, C. A., \& Horn, R. A. (2007). An examination of Pace's model of student development and college impress. Community College Journal of Research and Practice, 31(3), 183-198.

Eyler, J. S., \& Giles, D. E., Jr. (1999). Where's the learning in service-learning? San Francisco, CA: Jossey-Bass.

Friere, P. (1970). Pedagogy of the oppressed. New York, NY: Herder and Herder.

Gale, T. (2000). Rethinking social justice in schools: How will we know we recognize it when we see it? International Journal of Inclusive Education, 4(3), 253-269.

Giles, D. \& Eyler, J. (1994). The theoretical roots of service-learning in John Dewey: Toward a theory of service-learning. Michigan Journal of Community Service Learning, 1(1), 77-85.

Eyler, J., Giles, D. E. Jr., \& Schmiede, A. (1996). A practitioner's guide to reflection in service-learning: Student voices \& reflections. Nashville, TN: Vanderbilt University.

Gray, M. J., Ondaatjte, E. H., Fricker, R. Gershwind, S., Goldman, C. A., Kaganoff, T., et al. (1998). Coupling service and learning in higher education: The final report of the evaluation of the Learn and Serve America, Higher Education Program. Place: RAND Corporation.

Hannay, L., Wideman, R., \& Seller, W. (2006). Professional learning to re-shape teaching. Toronto, ON: Elementary Teachers' Federation of Ontario.

Keen, C., \& Keen, J. (1998). Bonner Student Impact Survey. Retrieved from: http:// bonnernetwork.pbworks.com/w/page/13113181/Student\%20Impact\%20Survey

Kuh, G. D., Kunzie, J., Schuh, J. H., Whitt, E. J., \& Associates. (2005). Student success in college: Creating conditions that matter. San Francisco: Jossey-Bass.

Longo, N. V., \& Meyer, R. P. (2006). College students and politics: A literature review (CIRCLE Working Paper 46). College Park, MD: Center for Information and Research on Civic Learning and Engagement.

Marullo, S., \& Edwards, B. (2000). From charity to justice: The potential for universitycommunity collaboration for social change. American Behavioural Scientist, 43, 895912.

National Commission on Service-Learning. (2002). Learning in deed: The power of service-learning for American schools, Chambers, T.

Pace, C. R. (1979). Measuring outcomes of college: Fifty years of findings and recommendations for the future. San Francisco, CA: Jossey-Bass. 
Pace, C. R. (1984). Measuring the quality of college student experiences: An account of the development and use of the college student experiences questionnaire. Los Angeles, CA: University of California, Graduate School of Education, Higher Education Research Institute.

Pascarella, E. T., \& Terenzini, P. T. (2005). How college affects students: $A$ third decade of research (Vol. 2). San Francisco, CA: Jossey-Bass.

Rawls, J. (1971). A theory of justice. Oxford, UK: Oxford University Press.

Reardon, K. M. (1998). Participatory action research as RSL. New Directions for Teaching and Learning, 73, 37-44.

Rhodes, R.A. (April, 1997). Explorations of the caring self: Rethinking student development and liberal learning. Paper presented at the meeting of the American Educational Research Association, Chicago, IL.

Schutz, A., \& Ruggles, A. (1998). RSL and English studies: Rethinking “public” service. College English, 6o(2), 214-223.

Shinnamon, A., Gelmon, S., \& Holland, B. (1999). Methods and strategies for assessing service-learning in the health professions. San Francisco, CA: Community Campus Partnerships for Health.

Tartter, V. C. (1996). City College report to FIPSE. New York, NY: City College Research Foundation.

VanWynsberghe, R., \& Andruske, C. L. (2007). Research in the service of co learning: Sustainability and community engagement. Canadian Journal of Education, 30(1), 349376.

Weinberg, A.S. (2003). Negotiating community based research: A case study of the “Life's Work" project. Michigan Journal of Community Service-Learning, 9(3), 26-35.

Wiechman, M. C. (1996). Investigating urban community needs: RSL from a social justice perspective. Education and Urban Society, 28(2), 224-236.

Zlotkowski, E. (1996). Linking service-learning and the academy. Change, 28, 8-11.

\section{Contact Information}

Nancy Maynes

Schulich School of Education

Nipissing University

100 College Drive

North Bay ON P1A 1N6 Canada

nancym@nipissingu.ca

Nancy Maynes is Associate Professor of Education in the Schulich School of Education at Nipissing University, North Bay, Ontario, Canada. She teaches social studies and curriculum methods in the concurrent and consecutive education programs, and chaired the concurrent program from 2008 to 2011. She has authored Social Studies: Innovative Approaches for Teachers and Kindergarten in Canada: A Play-Based Approach for Edu- 
cators (both through Pearson Higher Education) as well as a course support manuscript about lesson planning and assessment called Focus on Learning: The Art and Science of Planning, Delivering, and Assessing Effective Lessons. Her research focuses on teacher preparation issues.

Blaine E. Hatt is Associate Professor of Education in the Schulich School of Education. He is a former secondary principal and a classroom teacher at the elementary and secondary levels. Presently, he teaches in undergraduate studies in curriculum and evaluation, English education, and imagination creativity education, as well as in graduate studies in literacy. His research focuses on pedagogical relationality, imagination creativity education, service learning, literacy, and understanding curriculum. He is a recipient of an inaugural Schulich Fellowship Award for Research.

Ron Wideman is Professor of Education in the Schulich School of Education at Nipissing University. He teaches in undergraduate and graduate studies in the areas of curriculum, leadership, and adult education. His research focuses on knowledge-creation approaches to professional growth including action research. He is Director of the Nipissing University Centre for the Study of Leadership and Ethics. 